\title{
Persistent Metopic Suture: a case reported from North East India
}

Dr Raktim Pratim Tamuli. Demonstrator, department of Forensic Medicine and Toxicology, Gauhati Medical College, Guwahati, Assam, India - 781032

Citation: Tamuli RP. Persistent Metopic Suture: a case reported from North East India. Int J Eth Trauma Victimology 2019; 5(1):45-46. doi.org/10.18099/ijetv.v5i1.7.

Article history

Received: Feb.12, 2019

Received in revised form: July 04, 2019

Accepted: Sept 5, 2019

Available online: Nov 05, 2019

Corresponding author

Dr Raktim Pratim Tamuli.

Demonstrator, department of Forensic Medicine and Toxicology, Gauhati Medical College, Guwahati, Assam, India - 781032

Phone: +919435164455

Email: raktimt81@gmail.com

Keywords: Death Certificate on Cause of Clinical Death; Cause of Death.

\section{Abstract}

Metopic suture is a kind of dentate suture extending from the nasion to the anterior angle of the bregma. Metopism is the condition where, persistence of metopic suture completely extends from nasion to bregma. Metopic suture usually obliterates by 2 years, but it has been reported to take up to seven years to fuse.

Examination of skeletal remains of a twelve-year-old girl shows obliteration two halves of the frontal bone in the skull. Dental examination shows presence of total 14 teeth in the upper jaw, including two $2^{\text {nd }}$ molars on each side.

Metopism at times may confusing during radiological examination of skull, as it may be misdiagnosed as fracture of skull bone.

\section{Introduction}

Metopic suture is a kind of dentate suture extending from the nasion to the anterior angle of the bregma. Metopism is the condition where, persistence of metopic suture completely extends from nasion to bregma (1). Metopic suture usually obliterates by 2 years (2), but it has been reported to take up to seven years to fuse (3).

A twelve-year-old girl was missing for 2-3 months and skeletal remains were found in a pond in the village where she was residing. Relatives identified the dead body from remaining wearing garments attached to the body. Examination of the skull bone shows non obliteration two halves of the frontal bone (Image I). Dental examination shows presence of total 14 teeth in the upper jaw, including two $2^{\text {nd }}$ molars, one on each side (Image II).

\section{Discussion}

Dental examination of this case shows that her age is more than 12 years (second molar is appeared, age of appearance 12-14 years) (4), and Metopic suture is not yet obliterated. From the findings it can be opined that, it is a case persistent Metopic suture or metopism.
Presence of metopism was once believed as a sign of intelligence because its presence related to growth of frontal lobes of brain as incidence was more in superior races and, rare in inferior races (5).

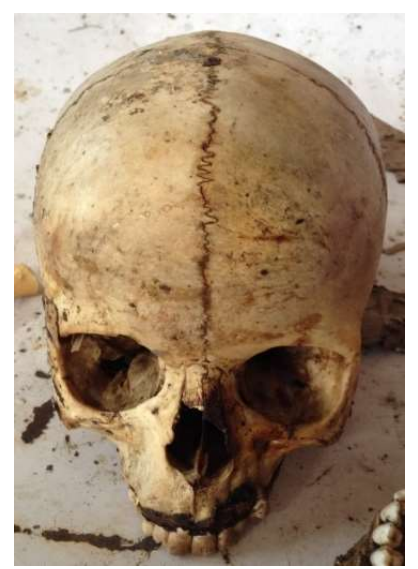

Fig.1. Persistent Metopic suture

Del Sol suggested that metopism can be related to abnormal growth of the cranial bones, hydrocephalus, heredity, or atavism (6). The genetic factor is the one currently accepted by 
most scientists (7). Metopism is found in approximately $5 \%$ of Asians and 9\% of European Caucasians and $1 \%$ of Blacks (8) (9). Bergman reported the persistence of the metopic suture in approximately $1-12 \%$ of skulls (9). Krogman in his book on "The Human Skeleton in Forensic Medicine" stated that, metopism is more frequent among whites and Mongoloids (about 10\%) than among Negroids (about2\%) (2).

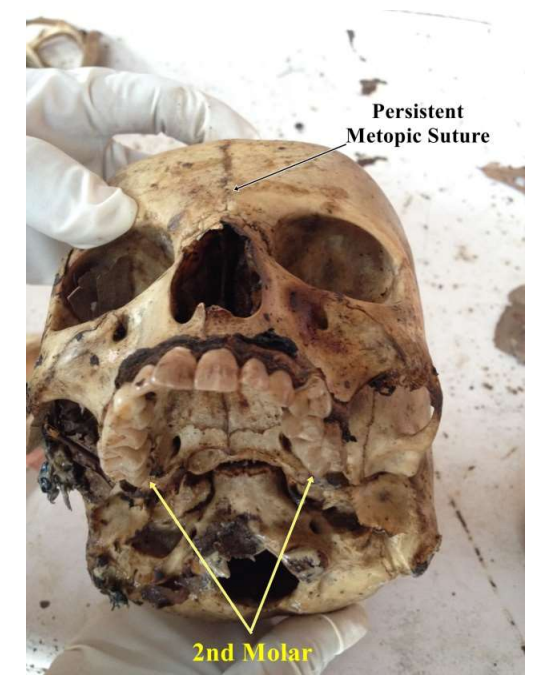

Fig.2. : Eruption of $2^{\text {nd }}$ molar teeth

Medico-legal importance: metopism can be confused with fracture of the skull during radiological examination of skull. It also helps at times in estimation of age.

\section{Conflict of Interest}

None declared

\section{References}

1. Bilodi AK, Agrawal BK, Mane S, Kumar A. A study of metopic sutures in human skulls.
Kathmandu Univ Med J KUMJ. 2004;2(2):96-9.

2. Krogman W. The Human Skeleton in Forensic Medicine. Illinois USA: Spingfield; 1962. 87-88 p.

3. Hamilton W. Metopic sutures in the skull. In: Textbook of Human Anatomy. 2nd ed. London: Macmillan \& Co; 1976. p. 60.

4. Kannan K, Modi MK. A textbook of medical jurisprudence and toxicology. Nagpur: LexisNexis; 2012. 280 p.

5. Vu HL, Panchal J, Parker EE, Levine NS, Francel $P$. The timing of physiologic closure of the metopic suture: a review of 159 patients using reconstructed 3D CT scans of the craniofacial region. J Craniofac Surg. 2001;12(6):527-532.

6. Falk D, Zollikofer CP, Morimoto N, de León MSP. Metopic suture of Taung (Australopithecus africanus) and its implications for hominin brain evolution. Proc Natl Acad Sci. 2012;109(22):84678470 .

7. Castilho SMA, Oda YJ, Santana GDM. Metopism in adult skulls from Southern Brazil. Int J Morphol. 2006;24(1):61-66.

8. Verma P, Mahajan A. Human skull with complete metopic suture and multiple sutural bones at lambdoid suture-a case report. Int J Anat Var. 2014;7(1).

9. Bergman RA, Thompson SA, Afifi AK, Saadeh FA. Compendium of human anatomic variation: text. Atlas World Lit Baltim. 1988; 